\title{
DOES ISLAMIC BANKING PROMOTE FINANCIAL STABILITY? EVIDENCE FROM AN AGENT-BASED MODEL
}

\author{
Omer Faruk Tekdogan ${ }^{1}$ and Burak Sencer Atasoy ${ }^{2}$ \\ ${ }^{1}$ Ministry of Treasury and Finance, Turkey, faruk.tekdogan@hmb.gov.tr \\ ${ }^{2}$ Ministry of Treasury and Finance, Turkey, burak.atasoy@hmb.gov.tr
}

\begin{abstract}
In recent years, Islamic banking has come to the forefront as one of the fastest growing branches of the global financial industry. In this study, we evaluate whether the coexistence of Islamic and conventional banks promotes financial stability. In this respect, we evaluate two types of financial system: (1) one solely comprising conventional banks, and (2) a dual system in which conventional and Islamic banks coexist and interact with each other. Accordingly, we designed two different agentbased models representing these systems and built two artificial banking networks consisting of both conventional and Islamic banks. We then ran simulations and examined possible contagion effects and the causes of bank failures by employing volatility spillover methodology. We found that Islamic banks significantly promote stability by providing liquidity during financial shocks and creating more liquidity per asset compared to conventional banks. We also found that they tend to hold more cash than conventional banks, which cushions the effects of possible liquidity squeezes. Conventional banks, on the other hand, tend to have reserve deficits, which rise during shock periods. We conclude that the coexistence of both bank types creates a win-win situation and contributes to financial stability.
\end{abstract}

Keywords: Islamic banking, Conventional banking, Contagion, Spillovers, Credit risk. JEL classification: G01; G2; G21; G28.

\author{
Article history: \\ Received : October 15, 2020 \\ Revised : February 8, 2021 \\ Accepted : : March 8, 2021 \\ Available online : May 20, 2021
}

https://doi.org/10.21098/jimf.v7i2.1323 


\section{INTRODUCTION}

\subsection{Background}

In recent years, Islamic banking has come to the forefront as one of the fastest growing branches of the global financial industry. During the period 2012-2018, total Islamic banking assets increased from $\$ 1,304$ billion to $\$ 1,760$ billion and the number of Islamic banks reached 520, with 301 fully-fledged Islamic banks and 219 Islamic windows around the globe (Mohamed \& Al Taitoon, 2019). As of 2019, the share of Islamic banking in the global banking system was around 6 percent, and was growing rapidly in several countries, especially in Asia and the MENA region. Islamic instruments are increasingly drawing the attention of investors, scholars, and policymakers since they represent a sturdy alternative to conventional banking.

Islamic banks are distinct from conventional ones in many aspects. Interest (riba) and uncertainty (gharar) are fordidden; money is not treated as a commodity; and the profits of depositors and costs of borrowers are not predetermined. Islamic banks are prohibited from using certain risky assets such as derivative contracts and are obliged to employ an asset-backed and risk-sharingbased banking methodology. Since Islamic banks are subject to a strict regulatory framework based on Shariah principles, they have less exposure to financial risks than conventional banks and remain isolated from financial distress. Several studies have argued that this strict framework was helpful during the global financial crisis (GFC) and that Islamic banks fared well, while conventional ones failed one after another (Hasan \& Dridi, 2011; Khediri, Charfeddine, \& Youssef, 2015; Parashar \& Venkatesh, 2010; Uddin, Chowdhury, \& Islam, 2017).

Usually, the stability of Islamic banks is inferred through comparative risk analysis with conventional banks. However, they coexist with conventional banks in many countries, despite operating under different principles. This involves the engagement of a lending-borrowing relationship between the two systems, although potential exposure arises through counterparty risk. Therefore, there is also the potential of creating contagion and risk transmission between the two systems since they are not completely isolated from each other.

Financial contagion can be defined as "the spread of market disturbances mostly on the downside - from one country to the other" (Dornbusch, Park, \& Claessens, 2000). Contagion, or the transmission of financial risks, can occur through several channels, such as liquidity (Claessens \& Dornbusch, 2001); crossmarket hedging (Pritsker, 2001); correlated information (King \& Wadhwani, 1990); asymmetric information (Kodres \& Pritsker, 2002); or wealth (Kyle \& Xiong, 2001). It can have either immediate or delayed effects (Tian \& Hamori, 2016), as well as direct and indirect ones (Clerc et al., 2016). Even if Islamic banks operate under different principles and employ less risky instruments compared to conventional ones, they may still encounter risks that could be worsened by the contagion channels stated above. Furthermore, even if conventional banks operate in a riskier fashion, contagion could also originate from Islamic banks. Accordingly, Islamic banks could become systematically important financial institutions (SIFI) as they grow and interact with conventional banks, as well as other Islamic banks. In this case, Islamic banks could become the risk transmitter rather than the risk receiver (Sole, 2007). Additionally, in countries where Islamic banks have a high 
market share, some could become too interconnected and remain at the epicentre of financial shocks. In this respect, financial stability assessments of Islamic banks should be performed using a holistic approach, taking into their interactions with the rest of the financial system.

\subsection{Objective}

We aim to evaluate whether the coexistence of Islamic and conventional banks promotes financial stability. In this respect, we evaluate two types of financial system: (1) one solely comprised of conventional banks, and (2) a system in which conventional and Islamic banks coexist and interact with each other. We first designed two agent-based models representing these systems. Im doing so, we not only compare the borrowing and lending relationships in the two systems, but also analyse financial phenomena such as fire sales and liquidity hoarding. Second, we examine possible contagious effects and the causes of bank failures in two the systems by employing the spillover methodology of Diebold and Yilmaz (2012), as well as graphical network analysis. Finally, we evaluate and compare financial stability in the two systems. To the best of our knowledge, this is the first study that compares conventional and Islamic banking models using an agentbased model and which analyses financial stability through spillover analysis.

The paper is organised as follows: Section 2 summarises the relevant literature, while Section 3 explains the data and methodology. Section 4 discusses model results, and Section 5 concludes and provides policy recommendations.

\section{LITERATURE REVIEW}

\subsection{Background Theory}

Theoretically, Islamic banking could contribute to financial stability as its transactions are asset backed and its instruments are designed to avoid excessive risk taking. Rather than offering a fixed rate of return on deposits, Islamic banks use a profit and loss sharing framework, in which customers share profits and losses with banks. In addition to risk sharing, Islamic banks also cannot participate in risky trading activities (Chong \& Liu, 2009). Interest-free banking, with proper implementation of profit-and-loss sharing, entails full disclosure and transparency, which ultimately serves to control imprudent lending and ensures the financial stability of the financial system. Many empirical studies have shown that interestfree banking is more rewarding than interest-based banking in sustaining financial stability and economic efficiency (Hassan \& Mahlknecht, 2011). Considering these unique features and comparing Islamic banking instruments with conventional ones, it could be argued that Islamic banks are more inclined to absorb financial shocks. Indeed, the literature includes several studies that assert the superiority of Islamic banking instruments (Baber, 2018; Khan, Khan, \& Tahir, 2017; Rashid, Yousaf, \& Khaleequzzaman, 2017). 


\subsection{Previous Studies}

There is a rich body of literature that assesses whether Islamic banking and financial practices are associated with higher or lower risk compared to their conventional counterparts. These studies proliferated after the GFC and provide mixed results.

Farooqi and O'Brien (2019) indicate that Islamic banks have lower operating risk and higher market risk compared to conventional ones in the Gulf State region, while Mohammad, Asutay, Dixon \& Platonova (2020) and Abdel Megeid (2017) find higher liquidity risk for Islamic banks. With regard to credit risk, Ferhi (2018), Chamberlain, Hidayat \& Khokhar (2020), Chamberlain et al. (2020), and Akram and Rahman (2018) find that this is lower for Islamic banks. Lassoued (2018), on the other hand, argues that Islamic banks have higher credit and insolvency risk compared to conventional banks and in general have a lower degree of stability. However, Kabir, Worthington, and Gupta (2015) find no significant difference in credit risk between Islamic and conventional banking systems. A similar finding was made by Harkati, Alhabshi, and Kassim (2020) who stress that the risktaking behaviour of Islamic banks is no different to that of conventional banks. These mixed findings on risk reflect the results of the studies that focus on the performance of Islamic and conventional banks during the GFC.

Some scholars argue that Islamic banks performed better during the GFC (Baber, 2018; Farooq \& Zaheer, 2015; Parashar \& Venkatesh, 2010; Rajhi \& Hassairi, 2013; Soedarmono, Pramono, \& Tarazi, 2017; Uddin et al., 2017), whereas others find no significant difference in the performance of the two types of bank (Abdulle \& Kassim, 2012; Alqahtani, Mayes, \& Brown, 2016; Beck, Demirguc-Kunt, \& Merrouche, 2013; Bourkhis \& Nabi, 2013; Kabir et al., 2015).

A strand of literature focuses on the stabilising role of Islamic banks and argues that Islamic banking could contribute to financial stability (Abedifar, Molyneux, \& Tarazi, 2013; Baele, Farooq, \& Ongena, 2014; Farooq \& Zaheer, 2015; Hussain, Shahmoradi, \& Turk, 2016; Pappas, Ongena, Izzeldin, \& Fuertes, 2017; Rahim \& Zakaria, 2013; Zehri \& Al-Herch, 2013). Some authors assert that only small Islamic banks are capable of promoting stability (Abedifar et al., 2013; Alqahtani \& Mayes, 2018; Cihak \& Hesse, 2010). Finally, some scholars conclude that Islamic banks do not play a stabilising role during times of financial distress and that conventional banks are superior in terms of financial stability (Alandejani, Kutan, \& Samargandi, 2017; Aysan \& Ozturk, 2018; Korbi \& Bougatef, 2017).

Another strand of literature asserts that Islamic markets are less vulnerable to crisis transmission and contagion due to their asset-backed nature. Among these studies, Rizvi, Arshad, and Alam (2015) analyse co-movements in Islamic and conventional stock markets across the US and Asia-Pacific between 1996-2014 by employing wavelet decomposition methodology. They find evidence of pure contagion until 2007, and fundamental-based contagion during the subprime crisis. They stress that Islamic stock markets have lower exposure to financial risks thanks to their low leverage, but underline that they are also more vulnerable as a result of their less diversified portfolios. Kenourgios, Naifar, \& Dimitriou (2016) used a multivariate APARCH-A-DCC framework to investigate pure contagion effects from international markets on Islamic bond and equity markets during the GFC and ESDC. They conclude that Islamic markets decouple from conventional ones during turbulent periods and can be used by investors to diversify their 
portfolios. A similar finding was made by Hkiri, Hammoudeh, Aloui, \& Yarovaya (2017), who also indicate that Islamic markets tend to decouple from their conventional counterparts during crises. In addition, Majdoub and Mansour (2014) found a weak correlation between the US and five Islamic emerging economy stock markets. They conclude that the asset-backed nature of Islamic markets reduces volatility spillovers from other markets. Finally, Mwamba, Hammoudeh, \& Gupta (2017) found that conventional stock markets had a higher probability of price drops during financial crises compared to Islamic ones. On the contrary, Hammoudeh, Mensi, Reboredo, \& Nguyen (2014) detected high dependence between conventional and Islamic markets and failed to validate the decoupling hypothesis. Yilmaz, Sensoy, Ozturk, \& Hacihasanoglu (2015) and Shahzad, Ferrer, Ballester, \& Umar (2017) also show that the decoupling hypothesis between conventional and Islamic markets does not hold, and that Islamic markets do not serve as a less risky alternative for investors who want to hedge.

Finally, many studies analyse financial contagion and systemic risk by performing simulations through agent-based models of interbank markets and credit interlinkages. Paulin, Calinescu, \& Wooldridge (2019) characterise systemic risk in terms of both system stability and the speed of financial distress propagation over intraday timescales. Arinaminpathy, Kapadia, and May (2012) designed a model banking system which combined three channels: liquidity hoarding, asset price contagion, and the propagation of defaults via counterparty credit risk. May and Arinaminpathy (2010) analysed the propagation of shocks in model banking networks by using analytic approximations, with emphasis on the interplay between the characteristics of individual banks and the overall dynamic behaviour of the system. Battiston et al. (2012a) explored the dynamics of default cascades in a network of credit interlinkages, while Battiston et al. (2012b) analysed the resilience of financial networks, concluding that the financial network is most resilient at an intermediate level of connectivity. The evolution of the credit network over time is characterised as a system of coupled stochastic processes. Tedeschi, Mazloumian, Gallegati, \& Helbing (2012) focus on how the emergent heterogeneity of market participants' interconnectedness affects the trade-off between mutual insurance and the potential for contagion, showing that higher bank connectivity not only increases agents' financial fragility, but also generates larger bankruptcy cascades due the higher systemic risk. Teply and Klinger (2018) investigated the real interconnectedness between nine Eurozone banking sectors thorough an agent-based model to estimate the levels of shock propagation caused by the defaults of multiple banks and that of an individual bank.

Chan-Lau (2017) analysed the risks in the banking system, in which banks' business decisions drive the endogenous formation of interbank networks thorough an agent-based model that shows the dynamics of solvency, liquidity and interconnectedness risk in response to shocks. Iori, Jafarey, \& Padilla (2006) studied the performance of the interbank market in its role as a safety net both for homogeneous and heterogeneous banks, by simulating interbank lending. Their results show that when banks are homogeneous, interbank lending stabilises the system, but tjhat higher reserve requirements can lead to a higher incidence of bank failures. When banks are heterogeneous, contagion effects may arise both directly and indirectly. Choi, Eisenbach, \& Yorulmazer (2016) analysed the effects 
and the timing of tools on both the investment efficiency that arises when less productive agents respond to monetary stimulus, and hoarding inefficiency when agents hoard liquidity rather than invest after monetary stimulus. Krause and Giansante (2012) modelled a network of interbank lending, in which banks were characterised by the amount of capital, cash reserves and their exposure to the interbank market, and analysed how the failure of a bank spreads in the banking system through interbank linkages. Liu, Paddrik, Yang, \& Zhang (2020) built an ABM with 6,600 banks, in which their decision rules and behaviours were reflected in quarterly balance sheets. The model was evaluated against the maximum entropy and minimum density algorithm approaches and showed results closer to actual financial network structures. De Caux, McGroarty, \& Brede (2018) analysed leverage cycles and financial contagion, in which banks could adapt their investment strategies according to the success of their competitors, creating an endogenous interbank loan network and a dynamic asset market. Channels for contagion are created endogenously by the traded asset market and interbank lending.

The literature on financial contagion and the role of Islamic banks in financial stability is extensive, although no study compares conventional and Islamic banking models using an agent-based model. Our study analyses financial contagion through an interbank network, not only for the conventional banking system, but also for the dual banking system involving Islamic banks, which enables a comparison to be made between the two systems.

\section{METHODOLOGY}

\subsection{Data}

We simulated the dynamics of financial contagion by building an artificial banking network model in which banks manage their liquidity by lending to or borrowing from other banks to avoid becoming illiquid. We performed 200 simulations $^{1}, 100$ of which included 15 conventional banks in a conventional banking system, and the other 100 including ten conventional and five Islamic banks in a dual banking system $^{2}$. The simulations were performed with heterogeneous banks for 2000 rounds, with a minimum reserve ratio of 10 percent.

By observing the general pattern of the results, we selected two representative simulations, one for the conventional system and the other for the dual system, to compare how financial risk spread ${ }^{3}$.

1 For other studies that employ simulations, see Chan-Lau (2017) and Tedeschi et al. (2012).

2 In some example countries, the number of conventional and Islamic banks are as follows, respectively: Indonesia 27 and 5; Turkey 28 and 6; Malaysia 26 and 16; and Pakistan 17 and 5. In line with this, we decided to include 10 conventional and 5 Islamic banks in our simulations.

3 The representative simulations exemplify the average number of failed banks. During the 200 simulations, two banks in the dual system and five in the conventional system failed. To save space, we omit the results of the simulations, which are available from the authors upon request. 


\subsection{Model Development}

The model describes a banking system with no government intervention and money is created endogenously by credit expansion. It includes two types of agent, conventional banks and Islamic banks, which are interconnected through a banking network. The key aspect of the model is the required reserve ratio, which banks should monitor and seek to maintain the required level.

In our model, both conventional and Islamic banks were divided into three categories according to the size of their total assets, namely big, medium and small. This classification provides a base to test the robustness of the model by checking whether big or small banks are more resilient to shocks.

Table 1 shows the balance sheet of a representative bank in the system. Assets consist of reserves (R), securities (S), loans (L), and interbank lending (IL), while liabilities include deposits (D), interbank borrowing (IB), and net worth (NW). NW is defined as the difference between assets and liabilities. For simplicity, reserves are assumed to also include cash. It should be noted that there are two types of securities - conventional and Islamic. Islamic banks can only trade Islamic securities, while conventional banks can only trade conventional ones.

Table 1.

Balance Sheet of a Representative Bank

\begin{tabular}{lc}
\hline Assets & Liabilities \\
\hline Reserves (R) & Deposits (D) \\
Securities (S) & Interbank Borrowing (IB) \\
Loans (L) & Net Worth (NW) \\
Interbank Lending (IL) & \\
\hline
\end{tabular}

Each bank has other attributes, such as loan supply (LS), loan demand (LD), interbank loan supply (ILS), interbank loan demand (ILD), deposit rates $\left(r^{d}\right)$, and lending rates $\left(r^{l}\right)$, which are calculated at each round after each transaction.

Loan demand is exogenous and the loan demand growth rate is assumed to randomly float between $0 \%$ and $0.1 \%$ at each round. Therefore, despite decreasing during crisis periods, total loan stock has a tendency to increase in the long run. Loan supply becomes zero when a bank fails to meet the minimum reserve requirement. Conditional on meeting the minimum reserve requirement, a bank's loan supply is determined by liquidity and capital adequacy, which is shown in formula (1):

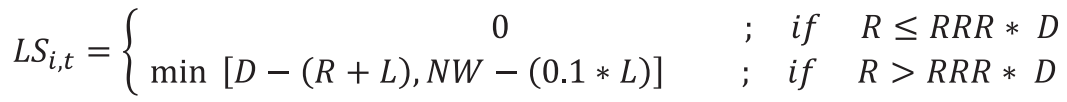

where i denotes bank name and $t$ denotes time.

Each bank has differentiated lending and deposit rates, which are dependent on the lending and deposit rates of previous rounds, the interbank rate, and banks' loan supply and demand. Since there are two separate interbank markets for 
conventional and Islamic banks, benchmark interbank rates differ according to the bank type. The lending rate rises with excess loan demand and falls with excess loan supply. Lending and deposit rates are denoted in formulas (2) and (3), respectively ${ }^{4}$.

$$
\begin{aligned}
& r_{i, t}^{l}=\left\{\begin{array}{l}
{\left[r_{i, t-1}^{l}+\left[r_{t}+\left(1-\left(L S_{i, t}-L D_{i, t}\right) / L S_{i, t}\right)\right]\right] / 2 \quad ; \quad \text { if } \quad L S_{i, t}>L D_{i, t}} \\
{\left[r_{i, t-1}^{l}+\left[r_{t}+\left(1+\left(L D_{i, t}-L S_{i, t}\right) / L D_{i, t}\right)\right]\right] / 2 \quad ; \quad \text { if } \quad L S_{i, t} \leq L D_{i, t}}
\end{array}\right. \\
& r_{i, t}^{d}=\left[r_{i, t-1}^{d}+\left(r_{i, t}^{l}-r_{t}\right)\right] / 2
\end{aligned}
$$

A bank's excess reserves determine whether it is a lender or borrower in the interbank market; it becomes a lender if its reserves are higher than those required, otherwise it becomes a borrower. Interbank loan demand and supply are determined by the following formulas:

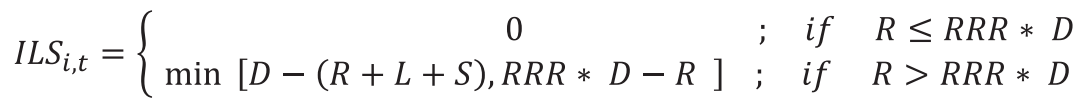

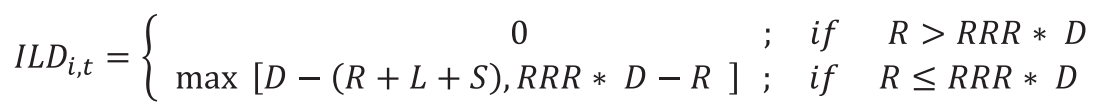

The interbank rate is determined endogenously in the interbank market. Accordingly, excess aggregate supply leads to a lower rate and excess aggregate demand leads to a higher rate. The interbank rate floats between the lower and upper bounds of $0 \%-2 \%$, as suggested by formula (6):

$$
r_{t}=\left\{\begin{array}{l}
1-\left[\left(\sum I L S_{t}-\sum I L D_{t}\right) / \sum I L S_{t}\right] \\
1+\left[\left(\sum I L D_{t}-\sum I L S_{t}\right) / \sum I L D_{t}\right]
\end{array} \quad ; \quad \text { if } \quad \sum I L S_{t}>\sum I L D_{t}\right.
$$

\subsubsection{Money Creation}

Endogenous money creation constitutes the cornerstone of the model. As discussed in Cincotti, Raberto, and Teglio (2010), the literature defines several channels of money creation, most of which involve central bank activities. In our model, however, we only consider a single channel due to the absence of a central bank. Accordingly, when households and firms borrow from banks, new money is created in the form of deposits. Consequently, money is created endogenously through bank lending. On the other hand, to reflect daily banking operations in which deposits and cash are transformed, the deposits are allowed to fluctuate randomly within a narrow band. Similarly, taking into account the possibility that loans can be repaid before the due date or defaulted, the number of outstanding loans is also allowed to fluctuate randomly within a narrow band.

${ }^{4} r_{i, t}{ }^{l}$ and $r_{t}$ are assumed to be positive, whereas $r_{i, t}{ }^{d}$ could be either positive or negative. 


\subsubsection{Interbank market}

Our model requires banks to maintain a certain reserve ratio. In the case of a reserve gap, banks may seek funding from other banks with excess reserves in the interbank market at interbank rates. However, banks cannot borrow again without completely paying back these i loans. There are two separate interbank markets for conventional and Islamic banks. The logic is that conventional banks' interbank funding transactions are interest rate based, whereas Islamic banks use Islamic modes of financing. In practice, Islamic banks occasionally form bilateral financing arrangements with conventional banks. In our model, we applied one-way financing; that is, if a conventional bank cannot find funding in the conventional interbank market, it can seek funding from the Islamic one. However, the reverse facility does not exist for Islamic banks.

\subsubsection{Securities market}

There is the possibility that a bank fails to access funding from the interbank market. Therefore, by taking into account the absence of a lender of last resort, banks can resort to the securities market and maintain the required reserves by selling their securities at a discount rate. The model introduces two distinct markets for conventional and Islamic securities, in which conventional banks can only trade conventional securities and Islamic banks can only trade Islamic ones. There is no interaction between these two markets. Banks with excess loan supply, which they were not able to sell on the credit or interbank market because of lack of demand, can also buy securities and earn interest (profit) on them. The interest (profit) rates on securities are dependent on interbank rates, in which the discount rates for selling and buying securities are 200 and 100 basis points respectively. In order to induce banks to use the interbank market as the primary source of funding, the securities market becomes operational every 25 rounds, rather than being continually active. A fire sale mechanism emerges during shock periods, in which banks can liquidate their securities in the case of a shortage of liquidity. It is assumed that there are an infinite number of buyers and sellers in the securities market, therefore the market is large enough to absorb the supply of securities that emerges during turbulent times.

\subsubsection{Bank Failure}

The model includes a bank-run procedure to test banks' resilience during times of financial distress. This procedure begins periodically every 600 rounds and continues for 200 consecutive rounds. When the procedure begins, depositors rush to the banks to withdraw their deposits, which leads to a rapid reduction in banks' deposits and reserves. This affects borrowers' willingness to repay the loans and increases the number of non-performing ones. If banks begin to fail to obey the reserve requirement, this is tolerated up to a certain level, but they will go bankrupt after surpassing that level. The order of the procedures that the two types of bank follow during the simulation is shown in Figure 1. 


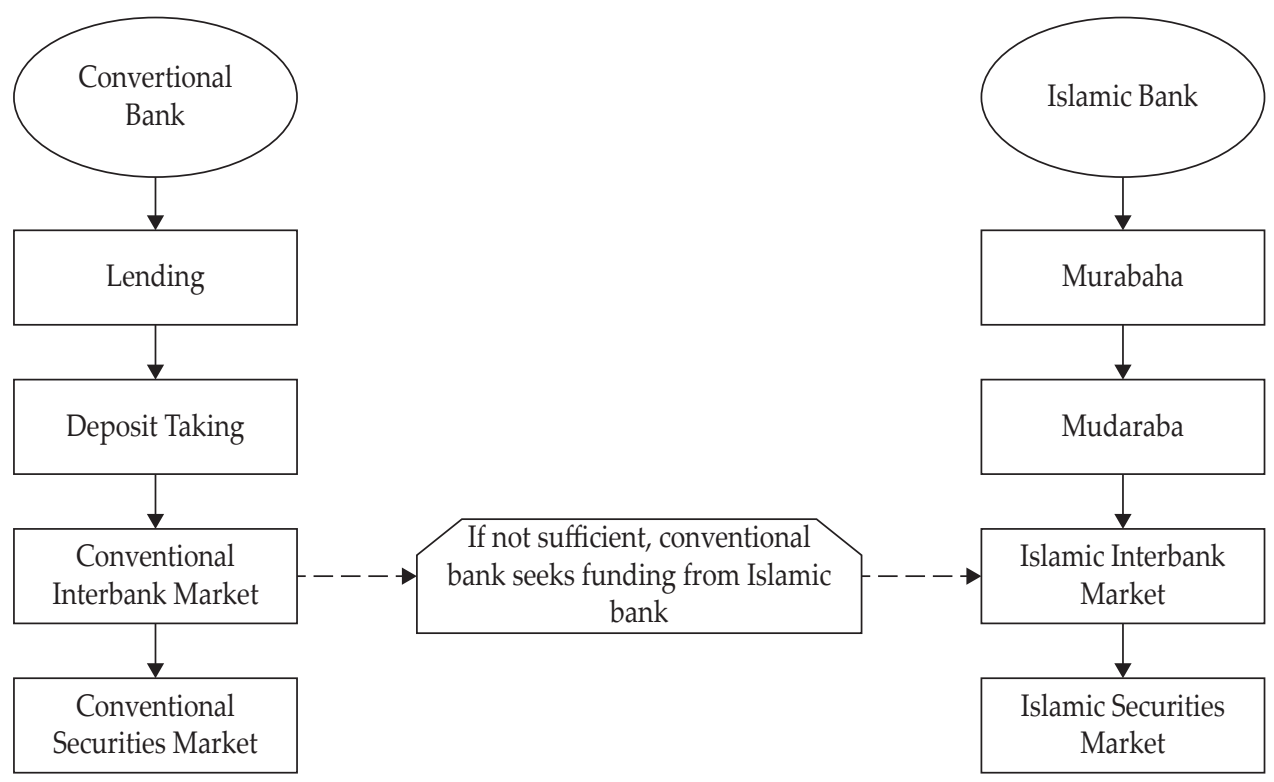

Figure 1.

Procedures for Conventional and Islamic Banks

\subsection{Model Assumptions}

The model involves a fixed minimum reserve ratio (MRR) at 10 percent and a capital buffer measured by the net worth/assets ratio. This is the only regulation.

Banks are heterogeneous. The model introduces three types of bank according to the size of their balance sheet (big, medium, and small). Initially, the banks' balance sheet items are determined randomly within the specified ranges for the three bank categories. This ensures that the banks are heterogeneous in size.

Neither the government nor central bank is involved. Hence, it is assumed that there is no state intervention or a lender of the last resort mechanism.

Banks operate based on collecting deposits and lending to consumers. The lending rate to consumers is determined endogenously by the previous bank lending rate, the interbank lending rate, and the balance between the bank's loan supply and demand.

Deposits are created endogenously through bank lending. It is assumed that the majority of the money lent by banks remains in the banking system in the form of deposits. Consequently, deposits also rise as lending increases. The deposit rate is determined endogenously by the previous deposit rate of the bank, the interbank lending rate, and the lending rate of the bank.

Interbank loan supply and demand is determined by deposits, reserves, and the reserve ratio. The maturity of interbank loans is one round; that is, interbank loans have to be paid back completely in the next round. Loan supply is determined by the banks' internal dynamics.

The interbank rate is determined endogenously by market conditions. It falls when supply exceeds demand and rises when demand exceeds supply. The interbank lending rate has a cap of $2 \%$. 
Loan quality is measured by the non-performing loan (NPL) ratio. This is determined exogenously and can increase or decrease by 0.5 per cent at each round. It has a cap of $6 \%$, which applies at $7.5 \%$ during shocks. The bank writes off bad loans when the NPL ratio reaches $6 \%$ during normal times and $7.5 \%$ during tumultuous times. The bank's net worth decreases by the amount of the write off.

The model includes a shock mechanism, a bank-run procedure which emerges periodically every 600 rounds and continues for 200 consecutive rounds. During this process, depositors rush to the banks to withdraw their deposits. The shock runs through two channels: a credit shock caused by borrowers' unpaid debt and a bank-run procedure caused by depositors. The capital adequacy of banks is measured by the net worth/assets ratio.

The model involves a fire sale mechanism. If a bank fails to find funding through the interbank market during shock periods, it is forced to sell securities in its balance sheet. The model includes a securities markets that is functional, with enough buyers and sellers. It is capable of absorbing the fire sale of securities during shock periods.

Banks become more cautious during shocks. They tend to hoard liquidity if they systematically fail to meet the reserve requirement. This makes them reluctant to lend in the interbank market, so the system becomes prone to funding crises.

Banks default if they fail to meet the liquidity conditions set by the model. Banks that fail to obey the reserve requirement are tolerated up to a certain level; those that surpass this level go bankrupt and are removed from the system.

There is no acquisition. A proportion of failed banks' assets and liabilities are distributed evenly to the remaining banks. Nevertheless, the interbank claims and liabilities of a failed bank are written off from the counterparty balance sheets.

\subsection{Diebold-Yilmaz Spillover Methodology}

In order to gauge the spillover effects of bank failures, we employed Diebold \& Yilmaz (2012) connectedness methodology, which involves generating connectedness measures based on forecast error variance decomposition (FEVD) of a generalised vector autoregressive process. The Diebold \& Yilmaz (2012) approach (hereafter DY) is an advanced version of the Diebold \& Yilmaz (2009) volatility spillover measure, which yields directional and net spillovers, in addition to total spillovers. The DY approach adopts a generalised vector autoregressive framework in which FEVDs are invariant to the variable ordering and generate directional volatility spillovers.

Consider an N-variable VAR process $X_{t}=\sum_{i=1}^{p} \gamma_{i} X_{t-i}+\varepsilon_{t}$, where $\gamma_{i}$ is a parameter matrix and $\varepsilon$ is a vector of iid disturbances $\left[\varepsilon_{t} \sim(0, \Sigma)\right]$. Assuming covariance stationarity, the VAR model could be denoted by a moving average representation, $X_{t}=\sum_{i=0}^{\infty} A_{i} \varepsilon_{t-i}$, where $A_{i}=\gamma_{1} A_{i-1}+\gamma_{2} A_{i-2}+\cdots+\gamma_{p} A_{i-p}$ with $A_{0}$ being an $N x N$ identity matrix and $A_{i}=0$ for $i<0$. It is also possible to cluster the generalized FEVD (GFEVD) into components caused by shocks to the different variables the system for a given forecast horizon H (Pesaran \& Shin, 1998). Consequently, the GFEVD could be calculated as follows: 


$$
\vartheta_{i j}(H)=\frac{\rho_{i j}^{-1} \sum_{h=0}^{H}\left(\left(\gamma_{h} \sum\right)_{i j}\right)^{2}}{\sum_{h=0}^{H}\left(\gamma_{h} \sum \gamma_{h}^{\prime}\right)_{i i}}
$$

where $\sum$ denotes the variance matrix for the error vector $\varepsilon, \rho_{i j}$ is the standard deviation of the error for the $j^{\text {th }}$ equation, and $\gamma_{h}$ denotes the $N x N$ matrix of coefficients responding to lag $h$. The GFEVD process assumes that the variance contribution of own and cross-variable is not necessarily equal to one ${ }^{5}$.

In order to compute the spillover index by utilising the information in the variance decomposition matrix, the effect attributable to each variable is standardised as follows:

$$
\tilde{\vartheta}_{i j}(H)=\frac{\vartheta_{i j}(H)}{\sum_{j=1}^{n} \vartheta_{i j}(H)}
$$

where $\sum_{j=1}^{n} \vartheta_{i j}(H)=1$ and $\sum_{i, j=1}^{n} \vartheta_{i j}(H)=N$, by definition. In equation $X$, $\tilde{\vartheta}_{i j}(H)$ yields pairwise connectedness measure from the $j^{\text {th }}$ variable to the $i^{\text {th }}$ variable at horizon $H$. Then, by utilising the volatility contributions from the variance decomposition, the total volatility spillover index can be calculated as follows:

$$
S(H)=\frac{\sum_{\substack{i, j=1 \\ i \neq j}}^{N} \widetilde{\vartheta}_{i j}(H)}{\sum_{i, j=1}^{N} \widetilde{\vartheta}_{i j}(H)} x 100=\frac{\sum_{\substack{i, j=1 \\ i \neq j}}^{N} \vartheta_{i j}(H)}{N} x 100
$$

The total spillover index gauges the contribution of volatility spillovers across different variables to the total forecast error variance. In addition, it is also possible to calculate the direction of spillovers across different variables with the help of the generalised VAR methodology. Accordingly, the directional spillovers received by market $\mathrm{i}$ from all other markets $\mathrm{j}$ are calculated by using the formula below:

$$
S_{i .}(H)=\frac{\sum_{\substack{j=1 \\ j \neq i}}^{N} \widetilde{\vartheta}_{i j}(H)}{\sum_{i, j=1}^{N} \widetilde{\vartheta}_{i j}(H)} \times 100=\frac{\sum_{\substack{j=1 \\ j \neq i}}^{N} \widetilde{\vartheta}_{i j}(H)}{N} \times 100
$$

Using the same methodology, the directional volatility spillovers transmitted by market $\mathrm{i}$ to all other markets $\mathrm{j}$ are calculated as:

$$
S_{. i}(H)=\frac{\sum_{\substack{J=1 \\ j \neq i}}^{N} \widetilde{\vartheta}_{j i}(H)}{\sum_{i, j=1}^{N} \widetilde{\vartheta}_{j i}(H)} x 100=\frac{\sum_{\substack{j=1 \\ j \neq i}}^{N} \widetilde{\vartheta}_{j i}(H)}{N} \times 100
$$

\section{RESULTS AND ANALYSIS}

\subsection{Results}

- Simulations were performed with 15 banks for 2000 rounds with a required reserve ratio of 10 percent. In the conventional system, all the banks were

${ }_{5}\left(\sum_{j=1}^{N} \vartheta_{i j}^{H} \neq 1\right)$. 
operating under conventional practices. In the dual system, banks 0-9 were operating under conventional practices, and 10-14 under Islamic practices ${ }^{6}$.

- Spillovers were calculated by using interbank borrowing amounts as input. Since the maturity of interbank loans is one round and these loans have to be paid back completely in the next round, unpaid loans are used as exposures between banks.

- Spillover tables depict the magnitude of exposure spillovers between banks for each period. Each period ends after a bank default. Since the number of defaulting banks varies between the conventional and dual models, there are four periods in the conventional system and three in the dual system.

- As Diebold and Yilmaz (2012) note, spillover tables should be interpreted as follows: the $(\mathrm{i}, \mathrm{j})^{\text {th }}$ entry is the estimated contribution to the forecast error variance of bank $\mathrm{i}$ originating from innovations to bank $\mathrm{j}$. The off-diagonal column sums and row sums, excluding the main diagonal elements, indicate the total spillovers transmitted to other banks (termed "TO") and transmitted by other banks (termed "FROM"), respectively. For example, according to Table 2, which shows the spillovers in the conventional system during the first period, innovations to Bank 0's exposures are responsible for $22 \%$ of the error variance in forecasting 10-step-ahead Bank 3's exposures.

- Figures 6 and 10 show the time-varying spillover indexes for the conventional and dual systems respectively. The figures are based on the forecast error variance decompositions of the 10-step-ahead forecasts, with 200-round rolling windows. Since spillovers are estimated by rolling window methodology and the spillovers of each period are calculated after removing defaulting banks from the sample, the time-varying spillover indexes have gaps.

- In the spillover tables shown in Tables 2-8, the variance decompositions are based on VAR(2) models, whose lag orders were selected according to the Schwarz information criterion (SIC).

- Network graphs indicate systems in which pairwise connections have some numerical values. They are generated by allocating a weight to each edge of the graphs. In this paper, we employed undirected graphs, whose edges link two vertices symmetrically, and the weights represent spillovers, as denoted in Tables 2-8. Network graphs are helpful in analysing interactions and spillovers between banks visually.

- Tables 2-5 and Figures 2-5 show the spillover tables and graphs of the conventional banking network respectively, while Tables 6-8 and Figures 7-9 show the spillover tables and graphs of the dual banking network respectively.

- Tables 9 and 10 show the net worth/asset ratios for the conventional and dual systems respectively.

- Figures 6 and 10 show the total volatility spillovers for the conventional and dual systems respectively.

\footnotetext{
6 According to the initial asset size, banks are classified as follows in the conventional system: small banks $(1,3,6)$; big banks $(0,2,5)$; medium banks (the rest). In the dual system, small banks are banks $1,3,10$, whereas big banks are banks 8,12 and 14 .
} 


\section{Conventional System}

- During the first three periods, Bank 0 is the largest transmitter of spillovers and around a quarter of total spillovers originate from this bank (Tables 2-5). Therefore, Bank 0 is the most influential bank in the conventional system.

- Bank 10 is the sole funder during the first and second shocks. It is also one of the three main funders with Banks 13 and 14 during the third shock. Therefore, Bank 10's funding is extremely important for overall liquidity during shock periods.

- Bank 8 fails after the first shock. Prior to its failure, its net worth/assets ratio was $12.6 \%$, whereas the average of all banks was $18 \%$. It becomes insolvent prior to 10 rounds of its failure. Interestingly, it has one of the highest initial net worth endowments (19.7\%) among the 15 banks.

- Bank 8's FROM spillovers (1.68) are very close to the average of total FROM spillovers (1.66) in the first period. Therefore, Bank 8 is not a general receiver of spillovers. However, it receives large spillovers from Bank 0 (9.53) in the first period. The bilateral lending-borrowing data also validate the high exposure of Bank 8 to Bank 0. Since the spillovers transmitted by Bank 8 are low, we should not worry about a contagion effect after its default.

- The second period starts without Bank 8. Similar to the first period, the net worth/assets ratio continues to decline throughout the sample, and at the end of the second period is $15.7 \%$. As seen in Figure 3, spillovers are concentrated among fewer banks.

- Bank 4 fails at the end of the second period, with a net worth/assets ratio of $13 \%$. This bank receives high spillovers from Bank 1 (13.25) during the second period, but those received from other banks are very limited. Similar to Bank 8, which failed during the first round, Bank 4 also exerts mild spillovers prior to its failure.

- The third period starts without Bank 4 . The average net worth/assets ratio falls to $15.3 \%$ during the second period; while the ratios of some banks fall below 10 percent, other banks manage to increase theirs. As seen in Figure 4, spillovers are concentrated further, while Bank 0 continues to remain at the epicentre of the spillover graph.

- Banks 2, 5 and 0 fail at the end of the third period, with net worth/assets ratios of $8 \%, 8.3 \%$ and $8.3 \%$ respectively. These banks fail due to capital inadequacy, although Banks 9 and 12 manage to survive despite having net worth/assets ratios below $10 \%$. This distinction is a result of access to liquidity during the second shock period, as Banks 9 and 12 manage to find ample liquidity, while the failed banks do not.

- Of the banks that fail at the end of third period,

- $\quad$ Bank 0 receives significant spillovers only from Bank 9.

- $\quad$ Bank 5 receives spillovers from Banks 0, 1, 6, 9.

- $\quad$ Bank 2 has the second lowest FROM spillovers of the 13 banks, but fails since it cannot roll over its debt.

- Bank 0 exerts consistently high spillovers to Banks 3, 7, and 9 during the first three periods, but these banks do not fail despite the failure of Bank 0 at the end of the third period. Bank 3 has one of the highest net worth/assets ratios and Banks 7 and 9 have no problem accessing liquidity during shocks. 


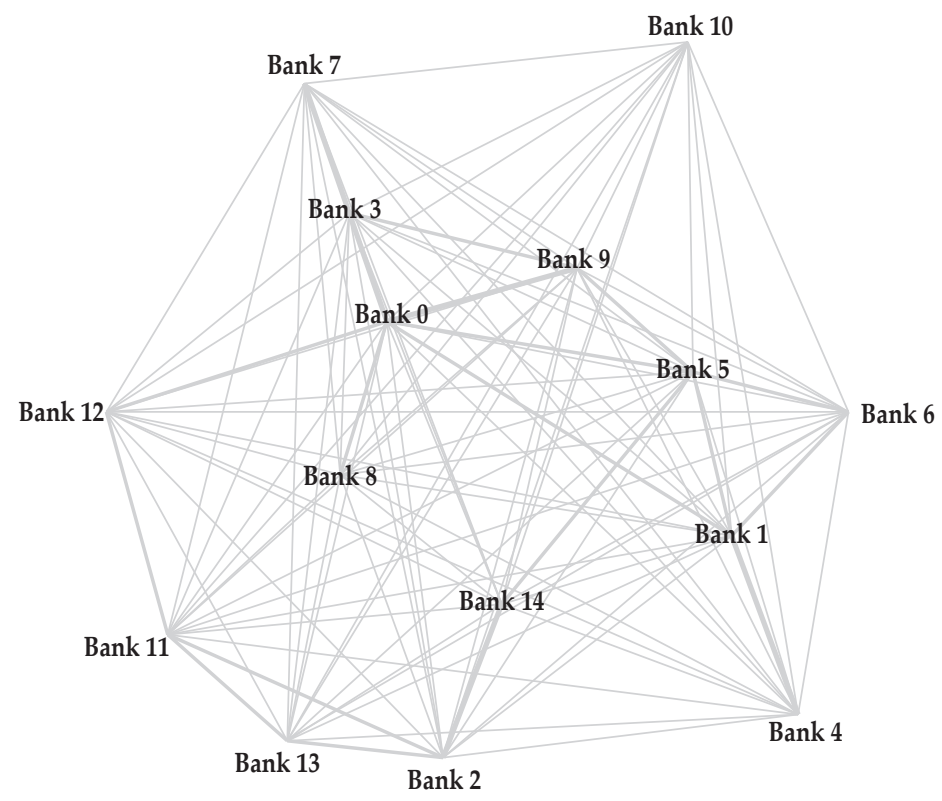

Figure 2.

Spillover Graph of the Conventional System in the First Period

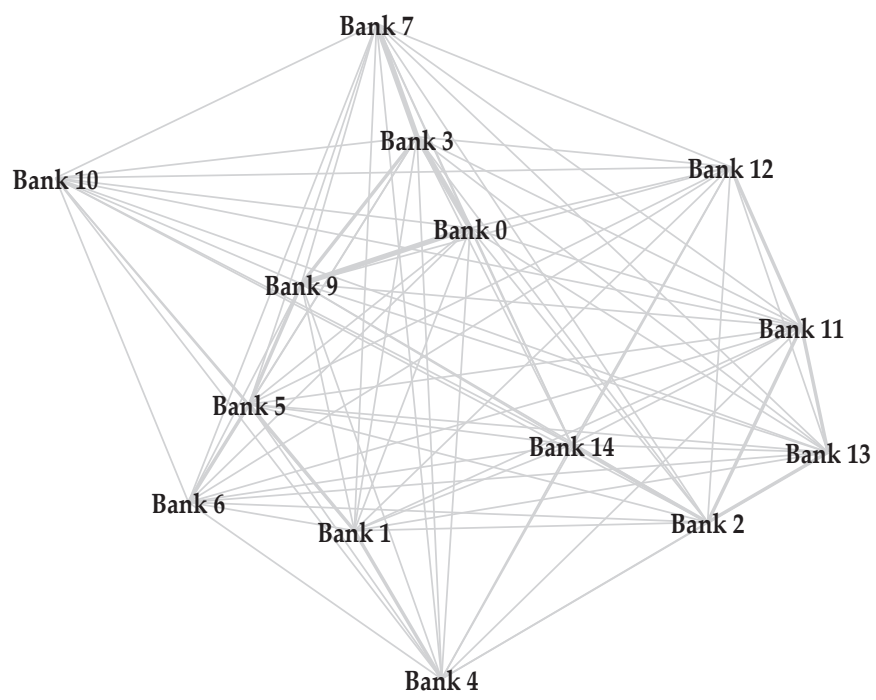

Figure 3.

Spillover Graph of the Conventional System in the Second Period 


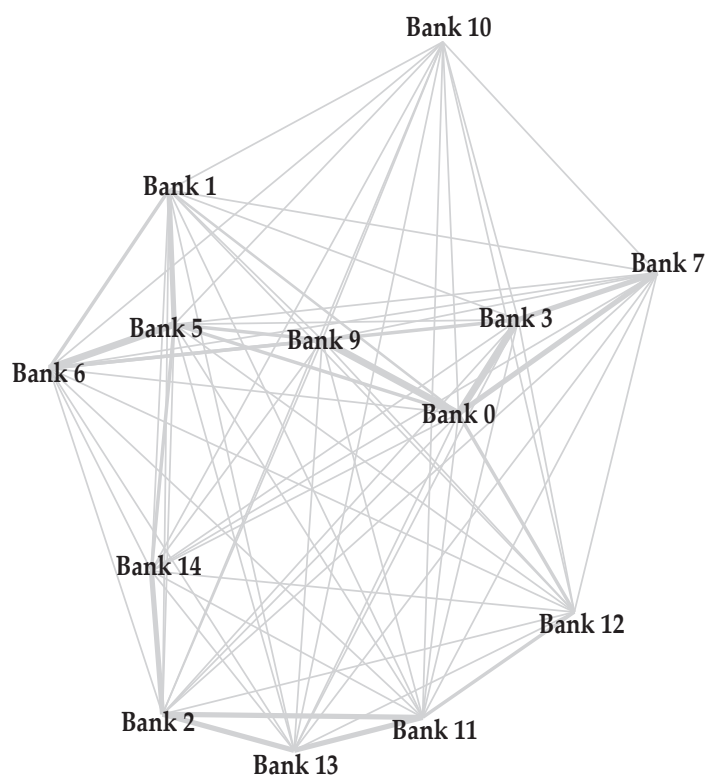

Figure 4.

Spillover Graph of the Conventional System in the Third Period

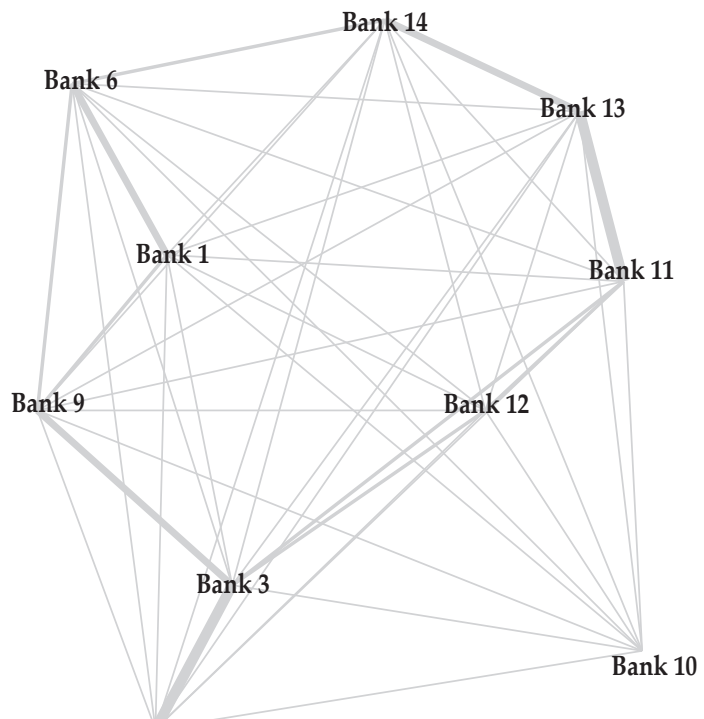

Bank 7

Figure 5.

Spillover Graph of the Conventional System in the Fourth Period

\section{Dual System:}

- During the simulation, Bank 0 is the largest transmitter of spillovers and around one-fifth of total spillovers originate from it (Tables 6-8). Therefore, Bank 0 is the most influential bank in the dual system. 
- Islamic banks 12 and 14 are the main lenders during the simulation, especially during shocks.

- Bank 1 fails after the first shock. Prior to its failure, it had a net worth/assets ratio of 28 percent, which is higher than the average. However, despite this high ratio, the bank has a persistent reserve deficit, which peaks during the first shock. Moreover, it receives spillovers from Bank 0, which is the leading transmitter of spillovers in the first period. Therefore, Bank 1 fails due to a liquidity shortage, as well as its exposure to Bank 0, rather than a capital inadequacy. Since spillovers transmitted by Bank 1 are mediocre, we should not worry about a contagion effect after its default.

- The second period starts without Bank 1, and the average net worth/assets ratio falls to $18.3 \%$ from $23.1 \%$ during this period. The fall in the ratio for Islamic banks (5.8 percentage points) is higher than that of conventional banks (4.2 percentage points).

- Bank 5 fails after the second shock. Prior to its failure, it had a net worth/assets ratio of $15.6 \%$, which is 2.7 percentage points below the average. Bank 5 also had a reserve deficit during the first shock, but it was not as high as that of Bank 1. The point in common between these two failures is debt repayment: both banks fail to repay their debt for 20 ticks prior to their failure.

- Bank 5 receives the largest spillovers from Banks 0, 2, and 4 during the second period. It is also the third largest transmitter of spillovers. In contrast to Bank 1's failure, that of Bank 5 has a tendency to create a contagion effect, as it not only receives significant spillovers, but also transmits them.

- Among the remaining eight conventional banks, Banks 4 and 8 have net worth/assets ratios well below the sample average. However, these banks avoid default since they manage to find funding from Islamic banks, Banks 12 and 14 in particular.

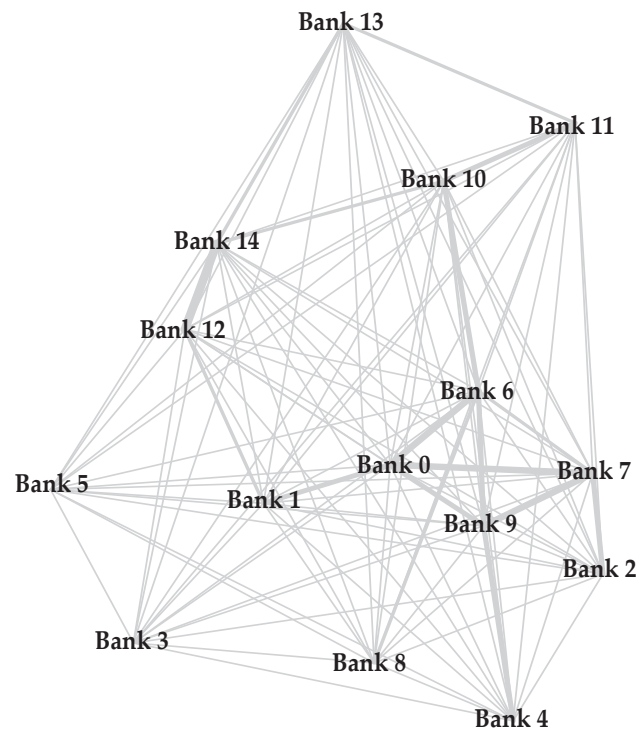

Figure 6. 




Figure 7.

Spillover Graph of the Dual System in the Second Period

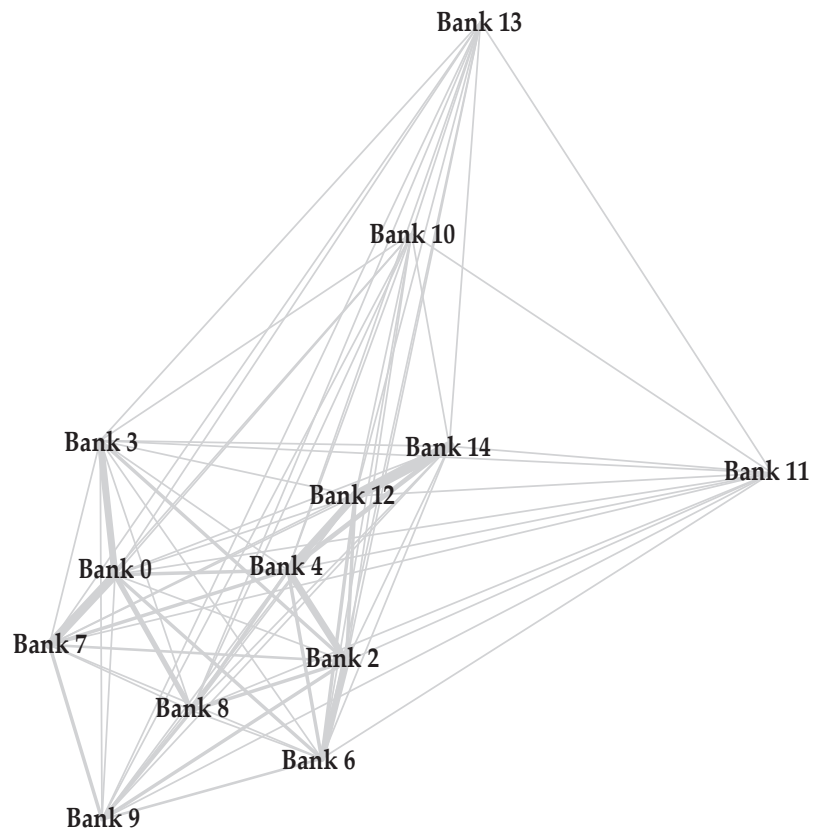

Figure 8.

Spillover Graph of the Dual System in the Third Period 


\subsection{Robustness Test}

To check the robustness of the results, we performed 200 simulations and noted the results in order to make a comparison between the conventional and dual systems. On average, more banks defaulted in the conventional system than the dual system. We selected two representative simulations and present their results. The results of the remaining simulations are omitted to save space, but are available upon request from the authors.

\subsection{Analysis}

In the first simulation, in which all the banks operate under conventional banking principles, five banks fail after three shocks. Bank 10 acts as a main funder during shocks, but it stops providing interbank loans during tumultuous periods. Due to the absence of liquidity, banks with low net worth/assets ratios fail. As for the dual system, two out of five Islamic banks (Banks 12 and 14) act as main funders and do not stop providing liquidity to the system, even during shocks. Thanks to the funding provided by Islamic banks during shock periods, no bank defaults in the third period, despite a sharp reduction in the net worth/assets ratios.

Islamic banks seem to be reluctant to engage in a borrowing-lending relationship with conventional banks during the first and second periods. This creates a discrete system, in which conventional and Islamic banks prefer to borrow and lend among their own classes. However, Islamic banks are integrated into the system from the end of the second period and play a crucial role in maintaining the stability of the system. This tendency is evident in Figures 6-8, where Islamic banks move closer to the epicentre of the network in each round.

Banks 12 and 14 have the lowest net worth/assets ratios among the 15 banks from the beginning of the simulation, yet they play a crucial role in stabilising the system. Accordingly, they only interact with other Islamic banks during normal times, but lend to conventional banks during shock periods, when liquidity is scarce due to reserve hoarding by the conventional banks.

Despite having low net worth/assets ratios, Banks 12 and 14 generate more liquidity per asset compared to conventional banks and operate more effectively. This finding is in line with the literature, which has found that Islamic banks create more liquidity per asset compared to conventional ones (Berger \& Bouwman, 2009; Berger, Allen, Boubakri, Guedhami, \& Li, 2019; Sahyouni \& Wang, 2019). Banks 12 and 14 also have the largest total assets among the Islamic banks, supporting the view that the stabilising role of Islamic banks strengthens when they become larger (Ibrahim \& Rizvi, 2017).

In our model, Islamic banks contribute to financial stability in two ways. First, by their nature, they tend to hold more cash compared to conventional banks, which cushions the effects of a possible liquidity squeeze (Dolgun, $\mathrm{Ng}$, \& Mirakhor, 2020). This propensity becomes more prominent as Islamic banks ration consumer loans in tumultuous periods and liquidate their assets (Beck et al., 2013). Second, since Islamic banks enter shock periods under excess reserves, their borrowing requirements decrease significantly, leading to a reduction in interbank borrowing between Islamic banks during shock periods. Conventional banks, on the other hand, tend to have reserve deficits, which intensify during shock periods. Given 
that Islamic banks have excess reserves and conventional banks have reserve deficits, it is rational for both sides to benefit from this situation and engage in a borrowing-lending relationship. Therefore, Banks 12 and 14, which have more excess reserves than the other Islamic banks, decide to lend to conventional banks that are in need of funding. By lending to these banks under financial distress, Banks 12 and 14 not only increase their profitability, but also contribute to the stability of the financial system by preventing prospective defaults.

\section{CONCLUSION AND RECOMMENDATIONS}

\subsection{Conclusion}

We have evaluated whether the coexistence of Islamic and conventional banks promotes financial stability. To this end, we assessed two types of financial system: (1) one comprised solely of conventional banks, and (2) a dual system in which conventional and Islamic banks coexist and interact with each other. Accordingly, we designed two agent-based models representing these systems and examined possible contagion effects and the causes of bank failures.

We found that Islamic banks greatly promote the stability of the system by providing liquidity during financial shocks and creating more liquidity per asset compared to conventional banks. We also found that they tend to hold more cash than conventional banks, which cushions the effects of possible liquidity squeezes. Conventional banks, on the other hand, tend to have reserve deficits, which intensify during shock periods. Given that Islamic banks have excess reserves and conventional banks have reserve deficits, it is rational for both sides to benefit from this situation and engage in a borrowing-lending relationship. Therefore, the coexistence of both bank types creates a win-win situation and contributes to financial stability.

\subsection{Recommendations}

Since Islamic banks have been found to contribute to financial stability, countries with no experience of Islamic banking practices could consider adopting such principles. In this way, the share of Islamic banking in the global banking system might increase and prospective financial crises might be prevented.

In terms of academic purposes, future work could focus on adding a government authority or a central bank to the model, as well as introducing an acquisition mechanism. It could also be interesting to run the simulations taking into consideration consumer behaviour.

\section{REFERENCES}

Abdel Megeid, N. S. (2017). Liquidity risk management: Conventional versus Islamic banking system in Egypt. Journal of Islamic Accounting and Business Research, 8(1), 100-128. https://doi.org/10.1108/JIABR-05-2014-0018.

Abdulle, M., \& Kassim, S. (2012). Impact of global financial crisis on the performance of Islamic and conventional banks: Empirical evidence from Malaysia. Journal of Islamic Economics, Banking and Finance, 8(4), 9-20. 
Abedifar, P., Molyneux, P., \& Tarazi, A. (2013). Risk in Islamic banking. Review of Finance, 17(6), 2035-2096.

Akram, H., \& Rahman, K. ur. (2018). Credit risk management: A comparative study of Islamic banks and conventional banks in Pakistan. ISRA International Journal of Islamic Finance, 10(2), 185-205. https://doi.org/10.1108/IJIF-09-20170030 .

Alandejani, M., Kutan, A. M., \& Samargandi, N. (2017). Do Islamic banks fail more than conventional banks? Journal of International Financial Markets, Institutions and Money, 50(September 2017), 135-155. https://doi.org/10.1016/j. intfin.2017.05.007.

Alqahtani, F., \& Mayes, D. G. (2018). Financial stability of Islamic banking and the global financial crisis: Evidence from the Gulf Cooperation Council. Economic Systems, 42(2), 346-360. https://doi.org/10.1016/j.ecosys.2017.09.001.

Alqahtani, F., Mayes, D. G., \& Brown, K. (2016). Economic turmoil and Islamic banking: Evidence from the Gulf Cooperation Council. Pacific-Basin Finance Journal, 39(C), 44-56.

Arinaminpathy, N., Kapadia, S., \& May, R. M. (2012). Size and complexity in model financial systems. PNAS, 109(45), 18338-18343. https://doi.org/10.1073/ pnas.1213767109.

Aysan, A. F., \& Ozturk, H. (2018). Does Islamic banking offer a natural hedge for business cycles? Evidence from a dual banking system. Journal of Financial Stability, 36(June 2018), 22-38. https://doi.org/10.1016/j.jfs.2018.02.005.

Baber, H. (2018). How crisis-proof is Islamic finance? : A comparative study of Islamic finance and conventional finance during and post financial crisis. Qualitative Research in Financial Markets, 10(4), 415-426. https://doi.org/10.1108/ QRFM-12-2017-0123.

Baele, L., Farooq, M., \& Ongena, S. (2014). Of religion and redemption: Evidence from default on Islamic loans. Journal of Banking $\mathcal{E}$ Finance, 44(July 2014), 141159. https://doi.org/https://doi.org/10.1016/j.jbankfin.2014.03.005.

Battiston, S., Delli Gatti, D., Gallegati, M., Greenwald, B., \& Stiglitz, J. E. (2012). Liaisons dangereuses: Increasing connectivity, risk sharing, and systemic risk. Journal of Economic Dynamics and Control, 36(8), 1121-1141. https://doi. org/10.1016/j.jedc.2012.04.001.

Battiston, S., Gatti, D. D., Gallegati, M., Greenwald, B., \& Stiglitz, J. E. (2012). Default cascades: When does risk diversification increase stability? Journal of Financial Stability, 8(3), 138-149. https://doi.org/10.1016/j.jfs.2012.01.002.

Beck, T., Demirguc-Kunt, A., \& Merrouche, O. (2013). Islamic vs. conventional banking: Business model, efficiency and stability. Journal of Banking E Finance, 37(2), 433-447.

Berger, A.N., \& Bouwman, C. H. (2009). Bank liquidity creation. The Review of Financial Studies, 22(9), 3779-3837.

Berger, Allen N., Boubakri, N., Guedhami, O., \& Li, X. (2019). Liquidity creation performance and financial stability consequences of Islamic banking: Evidence from a multinational study. Journal of Financial Stability, 44(October 2019), 100692. https://doi.org/10.1016/j.jfs.2019.100692.

Bourkhis, K., \& Nabi, M. S. (2013). Islamic and conventional banks' soundness during the 2007-2008 financial crisis. Review of Financial Economics, 22(2), 68-77. https://doi.org/10.1016/j.rfe.2013.01.001. 
Chamberlain, T., Hidayat, S., \& Khokhar, A. R. (2020). Credit risk in Islamic banking: evidence from the GCC. Journal of Islamic Accounting and Business Research, 11(5), 1055-1081. https://doi.org/10.1108/JIABR-09-2017-0133.

Chan-Lau, J. A. (2017). ABBA: An Agent-Based Model of the Banking System (No. WP17/136).

Choi, D. B., Eisenbach, T. M., \& Yorulmazer, T. (2016). Sooner or later: Timing of monetary policy with heterogeneous risk-taking. American Economic Review, 106(5), 490-495. https://doi.org/10.1257/aer.p20161077.

Chong, B. S., \& Liu, M. H. (2009). Islamic banking: Interest-free or interest-based? Pacific-Basin Finance Journal, 17(1), 125-144.

Cihak, M., \& Hesse, H. (2010). Islamic banks and financial stability: An empirical analysis. Journal of Financial Services Research, 38(2), 95-113.

Cincotti, S., Raberto, M., \& Teglio, A. (2010). Credit money and macroeconomic instability in the agent-based model and simulator eurace. Economics: The Open-Access, Open-Assessment E-Journal, 4(2010-26). https://doi.org/10.5018/ economics-ejournal.ja.2010-26.

Claessens, S., \& Dornbusch, P. Y. (2001). International financial contagion: How it spreads and how it can be stopped. In S. Claessens \& J. K. Forbes (Eds.), International Financial Contagion. (pp. 19 - 41). Boston: Kluwer Academic Publishers.

Clerc, L., Giovannini, A., Langfield, S., Peltonen, T., Portes, R., \& Scheicher, M. (2016). Indirect contagion: The policy problem. Occasional Paper Series No. 09 (January 2016). European Systemic Risk Board.

De Caux, R., McGroarty, F., \& Brede, M. (2018). Growth and collapse: An agentbased banking model of endogenous leverage cycles and financial contagion. International Journal of Computational Economics and Econometrics, 8(3-4), 370387. https://doi.org/10.1504/IJCEE.2018.096376.

Diebold, F. X., \& Y1lmaz, K. (2009). Measuring financial asset return and volatility spillovers, with application to global equity markets. The Economic Journal, 119(534), 158-171.

Diebold, F. X., \& Y1lmaz, K. (2012). Better to give than to receive: Predictive directional measurement of volatility spillovers. International Journal of Forecasting, 28(1), 57-66.

Dolgun, M. H., Ng, A., \& Mirakhor, A. (2020). Need for calibration: Applying a maximum threshold to liquidity ratio for Islamic banks. International Journal of Islamic and Middle Eastern Finance and Management, 13(1), 56-74. https://doi. org/10.1108/IMEFM-03-2018-0098.

Dornbusch, R., Park, Y., \& Claessens, S. (2000). Contagion: Understanding how it spreads. The World Bank Research Observer, 15(2), 177-197.

Farooq, M., \& Zaheer, S. (2015). Are Islamic banks more resilient during financial panics? Paific Economic Review, 20(1), 101-124.

Farooqi, M. F., \& O'Brien, J. (2019). A comparison of the impact of the Basel standards upon Islamic and conventional bank risks in the Gulf state region. Journal of Islamic Accounting and Business Research, 10(2), 216-235. https://doi. org/10.1108/JIABR-10-2016-0125.

Ferhi, A. (2018). Credit risk and banking stability: A comparative study between Islamic and conventional banks. International Journal of Law and Management, 60(4), 1009-1019. https://doi.org/10.1108/IJLMA-05-2017-0112. 
Hammoudeh, S., Mensi, W., Reboredo, J. C., \& Nguyen, D. K. (2014). Dynamic dependence of the global Islamic equity index with global conventional equity market indices and risk factors. Pacific-Basin Finance Journal, 30(November 2014), 189-206.

Harkati, R., Alhabshi, S. M., \& Kassim, S. (2020). Does capital adequacy ratio influence risk-taking behaviour of conventional and Islamic banks differently? Empirical evidence from dual banking system of Malaysia. Journal of Islamic Accounting and Business Research, 11(9), 1989-2015. https://doi.org/10.1108/ JIABR-11-2019-0212.

Hasan, M., \& Dridi, J. (2011). The effects of the global crisis on Islamic and conventional banks: A comparative study. Journal of International Commerce, Economics and Policy, 02(02), 163-200. https://doi.org/10.1142/ s1793993311000270.

Hassan, M. K., \& Mahlknecht, M. (2011). Islamic capital markets: Products and strategies (Vol. 4). Chichester: John Wiley and Sons.

Hkiri, B., Hammoudeh, S., Aloui, C., \& Yarovaya, L. (2017). Are Islamic indexes a safe haven for investors? An analysis of total, directional and net volatility spillovers between conventional and Islamic indexes and importance of crisis periods. Pacific-Basin Finance Journal, 43(C), 124-150.

Hussain, M., Shahmoradi, A., \& Turk, R. (2016). An overview of Islamic finance. Journal of International Commerce, Economics and Policy, 7(1), 1650003-1650101.

Ibrahim, M. H., \& Rizvi, S. A. R. (2017). Do we need bigger Islamic banks? An assessment of bank stability. Journal of Multinational Financial Management, 40(June 2017), 77-91. https://doi.org/10.1016/j.mulfin.2017.05.002.

Iori, G., Jafarey, S., \& Padilla, F. G. (2006). Systemic risk on the interbank market. Journal of Economic Behavior and Organization, 61(4), 525-542. https://doi. org/10.1016/j.jebo.2004.07.018.

Kabir, M. N., Worthington, A., \& Gupta, R. (2015). Comparative credit risk in Islamic and conventional bank. Pacific Basin Finance Journal, 34(September 2015), 327-353. https://doi.org/10.1016/j.pacfin.2015.06.001.

Kenourgios, D., Naifar, N., \& Dimitriou, D. (2016). Islamic financial markets and global crises: Contagion or decoupling? Economic Modelling, 57(September 2016), 36-46. https://doi.org/10.1016/j.econmod.2016.04.014.

Khan, I., Khan, M., \& Tahir, M. (2017). Performance comparison of Islamic and conventional banks: Empirical evidence from Pakistan. International Journal of Islamic and Middle Eastern Finance and Management, 10(3), 419-433. https://doi. org/10.1108/IMEFM-05-2016-0077.

Khediri, K. B., Charfeddine, L., \& Youssef, S. B. (2015). Islamic versus conventional banks in the GCC countries: A comparative study using classification techniques. Research in International Business and Finance, 33(January 2015), 75-98. https://doi.org/10.1016/j.ribaf.2014.07.002.

King, M., \& Wadhwani, S. (1990). Transmission of volatility between stock markets. Review of Financial Studies, 3(1), 5-33. Retrieved from https://econpapers.repec. org/RePEc:oup:rfinst:v:3:y:1990:i:1:p:5-33.

Kodres, L. E., \& Pritsker, M. (2002). A rational expectations model of financial contagion. Journal of Finance, 57(2), 769-799. 
Korbi, F., \& Bougatef, K. (2017). Regulatory capital and stability of Islamic and conventional banks. International Journal of Islamic and Middle Eastern Finance and Management, 10(3), 312-330. https://doi.org/10.1108/IMEFM-06-2016-0079.

Krause, A., \& Giansante, S. (2012). Interbank lending and the spread of bank failures: A network model of systemic risk. Journal of Economic Behavior and Organization, 83(3), 583-608. https://doi.org/10.1016/j.jebo.2012.05.015.

Kyle, A. S., \& Xiong, W. (2001). Contagion as a wealth effect. The Journal of Finance, 56(4), 1401-1440. https://doi.org/10.1111/0022-1082.00373.

Lassoued, M. (2018). Comparative study on credit risk in Islamic banking institutions: The case of Malaysia. Quarterly Review of Economics and Finance, 70(November 2018), 267-278. https://doi.org/10.1016/j.qref.2018.05.009.

Liu, A., Paddrik, M., Yang, S., \& Zhang, X. (2020). Interbank contagion : An agentbased model approach to endogenously formed networks. Journal of Banking $\mathcal{E}$ Finance, 112(March 2020), 105191.

Majdoub, J., \& Mansour, W. (2014). Islamic equity market integration and volatility spillover between emerging and US stock markets. The North American Journal of Economics and Finance, 29(July 2014), 452-470.

May, R. M., \& Arinaminpathy, N. (2010). Systemic risk : The dynamics of model banking systems. Journal of The Royal Society Interface, 7(46), 823-838. https:// doi.org/10.1098/rsif.2009.0359.

Mohamed, S., \& Al Taitoon, J. (2019). Islamic Finance Development Report 2019 Shifting Dynamics.

Mohammad, S., Asutay, M., Dixon, R., \& Platonova, E. (2020). Liquidity risk exposure and its determinants in the banking sector: A comparative analysis between Islamic, conventional and hybrid banks. Journal of International Financial Markets, Institutions and Money, 66(May 2020), 101196. https://doi. org/10.1016/j.intfin.2020.101196.

Mwamba, J. W. M., Hammoudeh, S., \& Gupta, R. (2017). Financial tail risks in conventional and Islamic stock markets: A comparative analysis. Pacific Basin Finance Journal, 42(April 2017), 60-82. https://doi.org/10.1016/j. pacfin.2016.01.003.

Pappas, V., Ongena, S., Izzeldin, M., \& Fuertes, A. M. (2017). A survival analysis of Islamic and conventional banks. Journal of Financial Services Research, 51(2), 221-256. https://doi.org/10.1007/s10693-016-0239-0.

Parashar, S. P., \& Venkatesh, J. (2010). How did Islamic banks do during global financial crisis?. Banks and Bank Systems, 5(4), 54-62.

Paulin, J., Calinescu, A., \& Wooldridge, M. (2019). Understanding flash crash contagion and systemic risk: A micro-macro agent-based approach. Journal of Economic Dynamics and Control, 100(March 2019), 200-229. https://doi. org/10.1016/j.jedc.2018.12.008.

Pesaran, H. H., \& Shin, Y. (1998). Generalized impulse response analysis in linear multivariate models. Economics Letters, 58(1), 17-29.

Pritsker, M. (2001). The Channels for Financial Contagion. In S. Claessens \& K. Forbes (Eds.), Intemational Financial Contagion (pp. 67-95). Boston: Kluwer Academic Publishers.

Rahim, M. S., \& Zakaria, R. H. (2013). Comparison on stability between Islamic and conventional banks in Malaysia. Journal of Islamic Economics, Banking and Finance, 9(3), 131-149. 
Rajhi, W., \& Hassairi, S. A. (2013). Islamic banks and financial stability: A comparative empirical analysis between Mena and Southeast Asian Countries. Région et Développement, 37(1), 1-31.

Rashid, A., Yousaf, S., \& Khaleequzzaman, M. (2017). Does Islamic banking really strengthen financial stability? Empirical evidence from Pakistan. International Journal of Islamic and Middle Eastern Finance and Management, 10(2), 130-148. https://doi.org/10.1108/IMEFM-11-2015-0137.

Rizvi, S. A. R., Arshad, S., \& Alam, N. (2015). Crises and contagion in Asia Pacific - Islamic v/s conventional markets. Pacific Basin Finance Journal, 34(September 2015), 315-326. https://doi.org/10.1016/j.pacfin.2015.04.002.

Sahyouni, A., \& Wang, M. (2019). Liquidity creation and bank performance: Evidence from MENA. ISRA International Journal of Islamic Finance, 11(1), 2745. https://doi.org/10.1108/IJIF-01-2018-0009.

Shahzad, S. J. H., Ferrer, R., Ballester, L., \& Umar, Z. (2017). Risk transmission between Islamic and conventional stock markets: A return and volatility spillover analysis. International Review of Financial Analysis, 52(July 2017), 9-26. https://doi.org/https://doi.org/10.1016/j.irfa.2017.04.005.

Soedarmono, W., Pramono, S. E., \& Tarazi, A. (2017). The procyclicality of loan loss provisions in Islamic banks. Research in International Business and Finance, 39(Part B), 911-919. https://doi.org/10.1016/j.ribaf.2016.05.003.

Sole, J. (2007). Introducing Islamic banks into coventional banking systems. IMF Working Papers, 07(175), 1-28. https://doi.org/10.5089/9781451867398.001.

Tedeschi, G., Mazloumian, A., Gallegati, M., \& Helbing, D. (2012). Bankruptcy cascades in interbank markets. PLoS ONE, 7(12), e52749. https://doi.org/10.1371/ journal.pone.0052749.

Teply, P., \& Klinger, T. (2018). Agent-based modeling of systemic risk in the European banking sector. Journal of Economic Interaction and Coordination, 14(4), 811-833. https://doi.org/10.1007/s11403-018-0226-7.

Tian, S., \& Hamori, S. (2016). Time-varying price shock transmission and volatility spillover in foreign exchange, bond, equity, and commodity markets: Evidence from the United States. The North American Journal of Economics and Finance, 38(November 2016), 163-171.

Uddin, A., Chowdhury, M. A. F., \& Islam, M. N. (2017). Resiliency between Islamic and conventional banks in Bangladesh: Dynamic GMM and quantile regression approaches. International Journal of Islamic and Middle Eastern Finance and Management, 10(3), 400-418. https://doi.org/10.1108/IMEFM-06-2016-0083.

Yilmaz, M. K., Sensoy, A., Ozturk, K., \& Hacihasanoglu, E. (2015). Cross-sectoral interactions in Islamic equity markets. Pacific-Basin Finance Journal, 32(April 2015), 1-20. https://doi.org/https://doi.org/10.1016/j.pacfin.2014.12.008.

Zehri, F., \& Al-Herch, N. (2013). The impact of the global financial crisis on the financial institutions: A comparison between Islamic banks (Ibs) and conventional banks (Cbs). Journal of Islamic Economics, Banking and Finance, 9(703), 69-88. 


\section{APPENDIX}

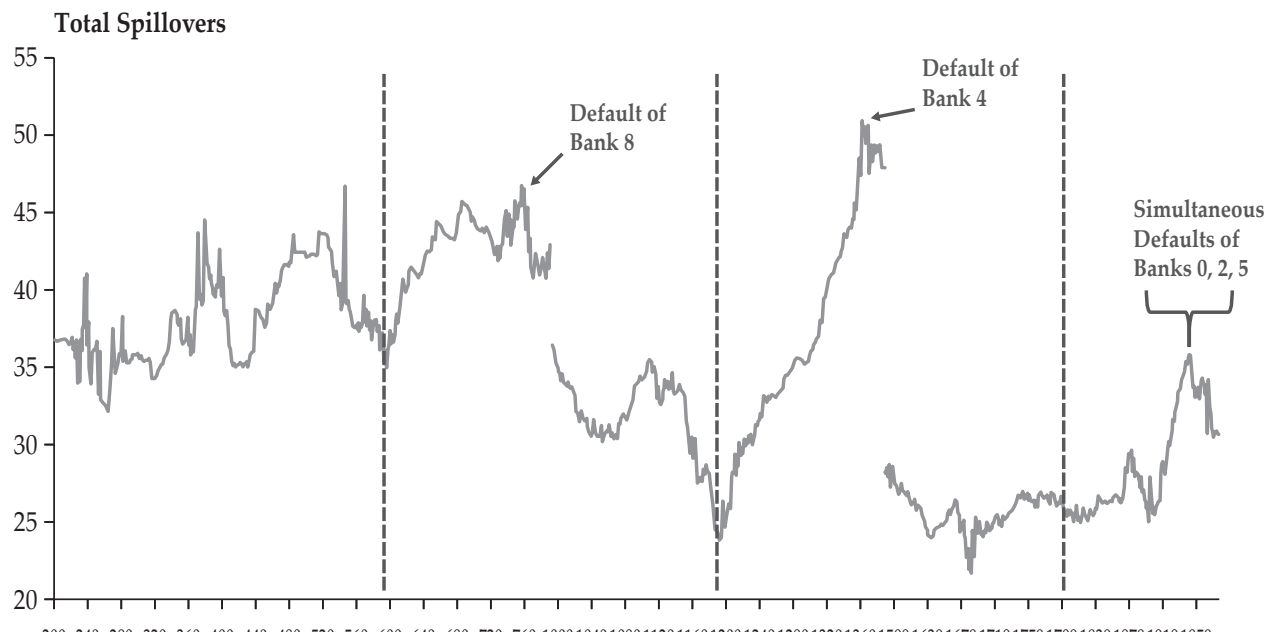

20024028032036040044048052056060064068072076010001040108011201160120012401280132013601599163916791719175917991839187919191959

Figure 9.

Total Volatility Spillovers Graph of the Conventional System



Figure 10.

Total Volatility Spillovers Graph of the Dual System 







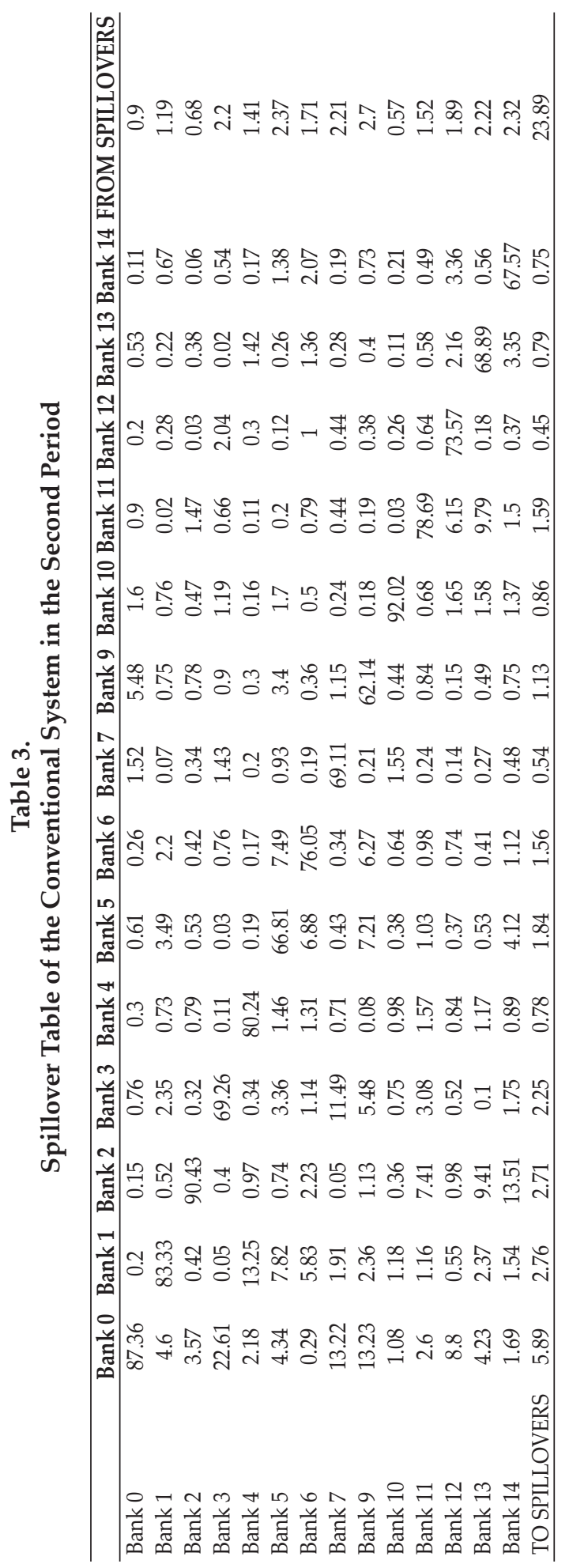




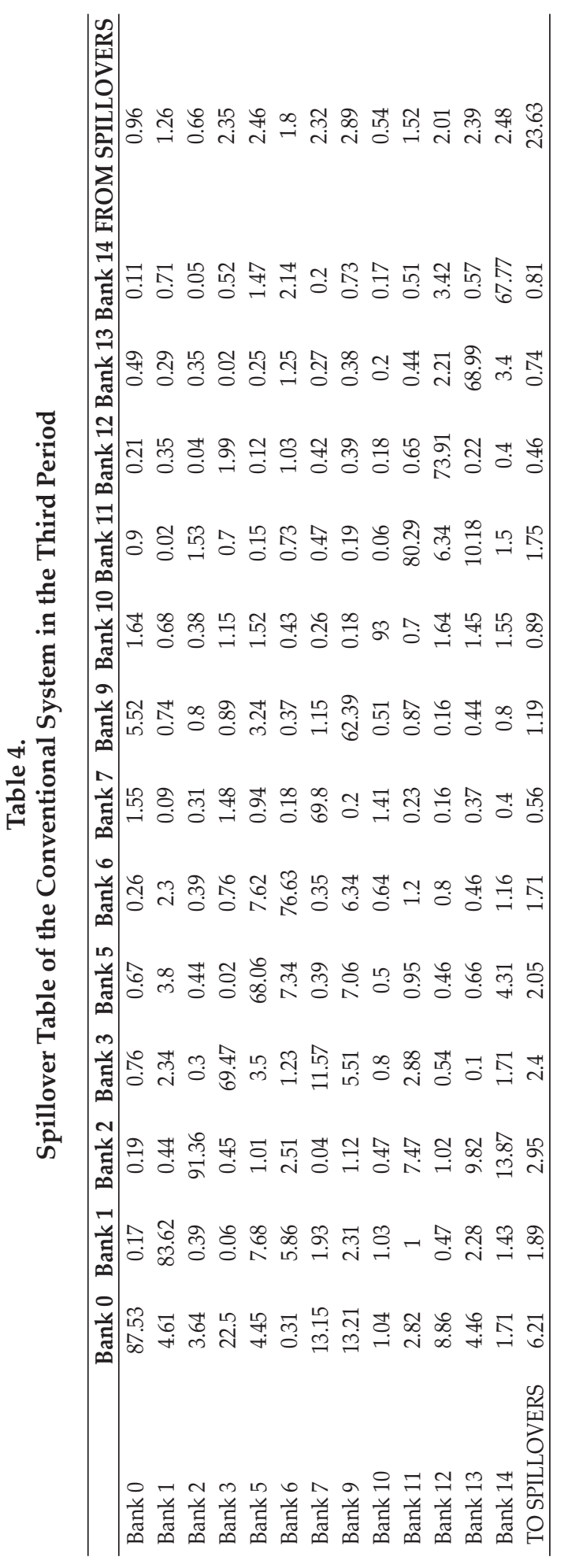



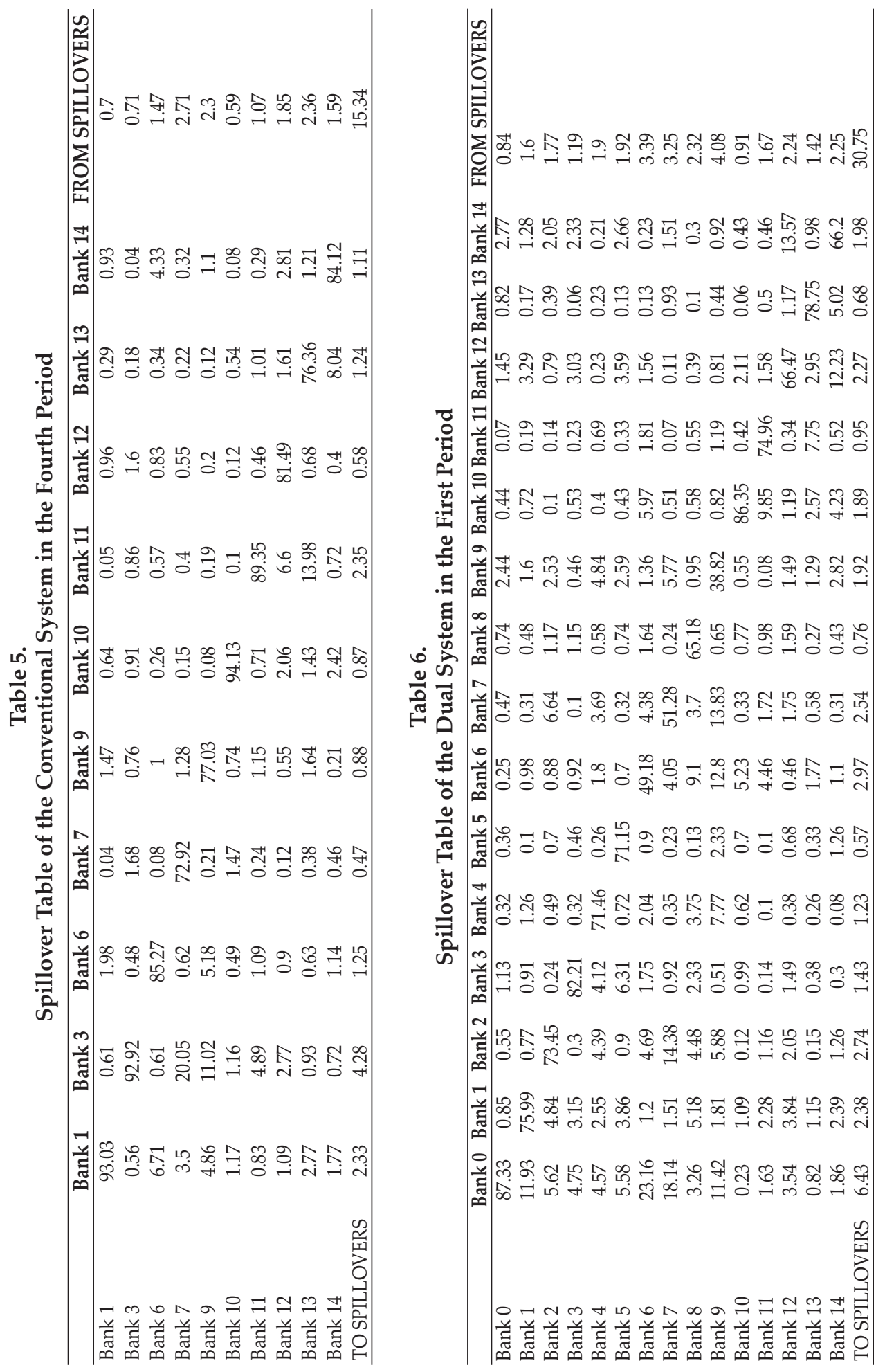


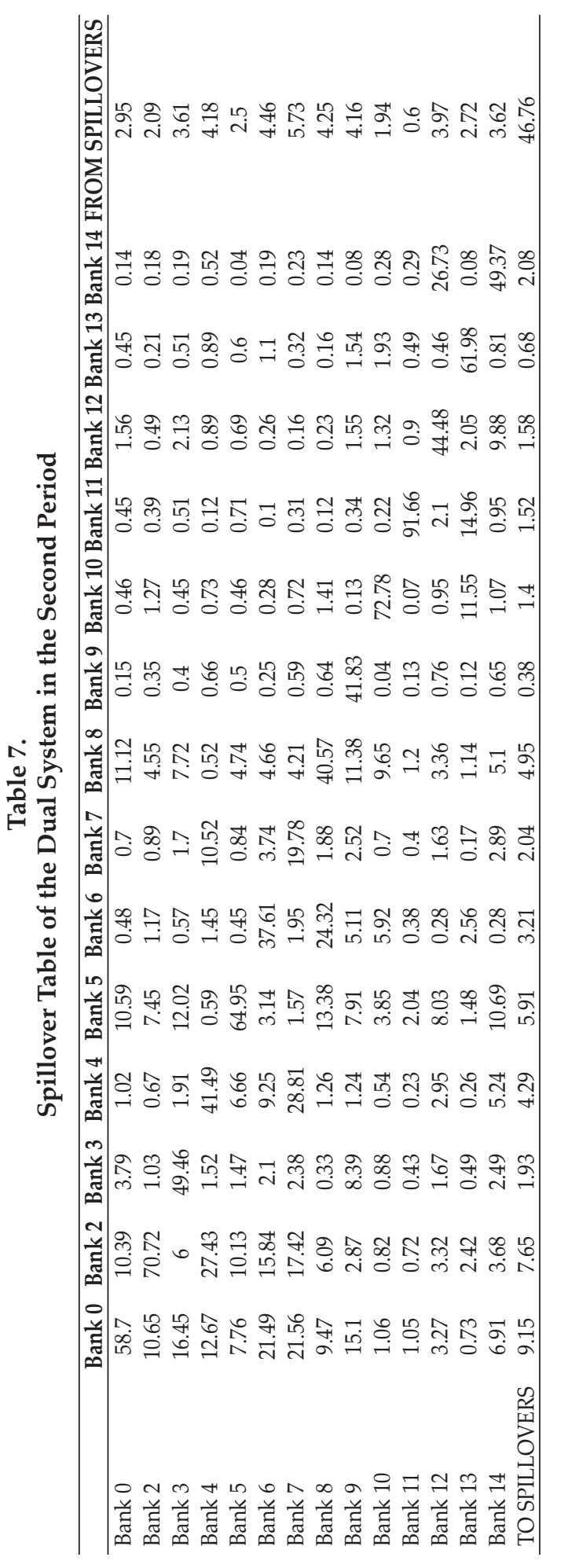



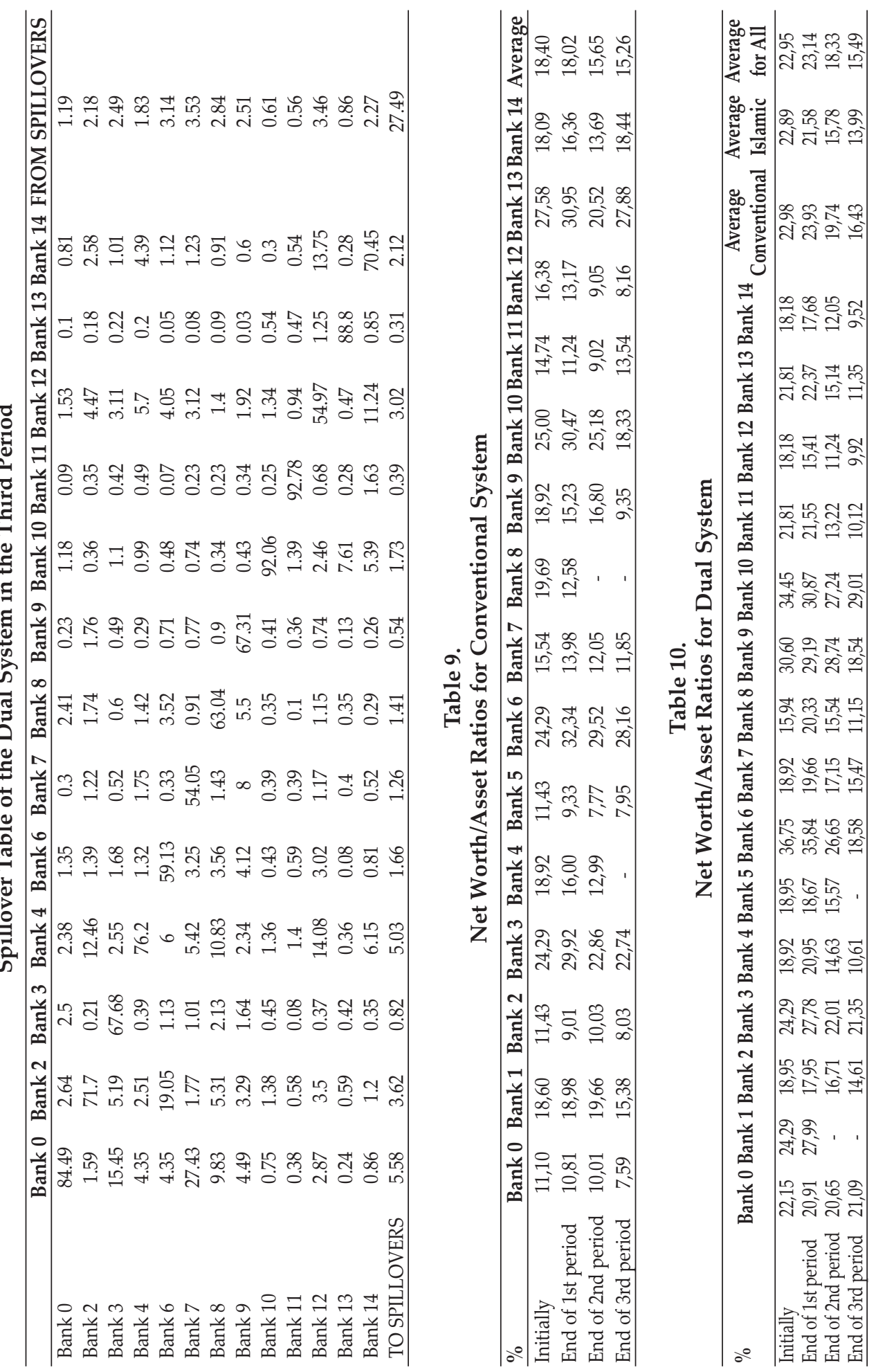